\title{
Neoclassical Realism and South Korea's Nuclear Weapons Policy
}

\author{
Clifton W. SherRILL*
}

This article develops a neoclassical realist model of decisionmaking that starts with the realist foundation of power, then layers on additional variables at both the domestic and individual levels. Based on a psychological conception of power, and differentiating the state, the regime, and the government, the model integrates prior neoclassical studies that emphasize elite perceptions, state structure, and strategic culture. As an illustrative example, the model is applied to South Korea's current policymaking regarding potential acquisition of nuclear arms. While South Korea is assessed to have sufficient power to pursue nuclear weapons, the lack of military utility coupled with likely harm to economic and reputational interests suggest continued rejection of such a policy.

Keywords: Neoclassical Realism, Foreign Policy, DecisionMaking, Nuclear Weapons, South Korea

\footnotetext{
* Assistant Professor, Troy University, USA

E-mail: csherrill@troy.edu

DOI: 10.16934/isr.16.1.201506.1
} 
Since North Korea's 2013 nuclear test, the question of whether South Korea might pursue nuclear weapons has received renewed attention (Dalton and Yoon 2013; Hibbs 2013; Weitz 2013; Ahn and Cho 2014). The failure of the Non-Proliferation Treaty (NPT), the Agreed Framework, the Six-Party talks and punitive sanctions to stop North Korea's nuclear arms program raises the issue of whether South Korea might revisit its nuclear decision. Although well-integrated into the global nonproliferation regime, South Korea faces an uncertain security environment, with dangerous trends.

First, the North Korean nuclear arms program appears to be making steady progress. By most accounts, North Korea is believed to have a handful of nuclear weapons, with reports suggesting plans for 20 weapons by the end of 2016 and 50 weapons by 2020 (Albright 2015; Arms Control Association 2015; Hecker 2015; Sanger 2015). North Korea possesses a variety of ballistic missiles capable of striking South Korea as well as U.S. forces in Japan, although it is not publicly clear whether North Korea has the ability to mate nuclear warheads to these missiles. North Korea continues to work on road-mobile ballistic missiles which would largely negate the option for a preemptive attack designed to eliminate North Korea's nuclear arsenal. Second, the extended deterrent protection offered to South Korea by the United States may be of declining value. U.S. officials have consistently downgraded the importance of nuclear arms through public rhetoric, reduction of the size of the U.S. nuclear arsenal, reduced funding for nuclear infrastructure, and refusal to develop new warheads or test current weapons for almost 25 years. ${ }^{1}$ Such actions may diminish North Korean perceptions as to the credibility of U.S. will to follow through on deterrent threats. Moreover, domestic U.S. issues, including effects of sequestration on the defense budget, reduction in the size of the armed forces, and war-fatigue from long-term deployments, raise issues for South Korean officials to consider when assessing the strength of the U.S.-ROK Mutual Defense Treaty. Third, rising Chinese military power and China's adoption of a counter-intervention, anti-access, area-denial (A2/AD) strategy due to interests outside the Korean peninsula call into question whether the United States will be able to maintain its long-term presence in Northeast Asia. Although China is likely content to have U.S. troops remain in South Korea as a stabilizing force, the A2/AD strategy could result in such troops being deprived of maritime and air support. Coupled with an economically-driven U.S. retrenchment, this could revive calls in the United States to bring Korean-based troops home. Taken together, these three factors could support a reevaluation by South Korean policymakers of nuclear policy.

Herein, I offer a neoclassical realist framework for explaining and predicting foreign policy decisions, using South Korean nuclear weapons policy as an illustrative case study. Although it provides a multi-level, inclusive approach to understanding foreign policy decision-making, it remains firmly grounded in the 
realist tradition. Power, as perceived by policymakers, stands as the primary causal variable. Yet, to understand what drives the power perceptions of these governing elites, it is necessary to consider factors such as state structure, strategic culture, and psychological biases. Prior neoclassical realist works have developed these ideas. The framework presented here integrates these factors, then adds consideration of parochial interests lurking in the principal-agent relationship of the state and its government. To be clear, the effort here is directed at theorybuilding; the analysis here does not engage in competitive hypothesis-testing. The remainder of the paper is organized as follows: Section one provides a brief overview of the theoretical landscape. Section two reviews the principles of neoclassical realism, followed by a detailed explanation of the specific version offered here. Thereafter, section three offers an illustrative example, applying these ideas to South Korea's decision-making regarding acquisition of nuclear weapons.

\section{FRAMEWORKS}

Foreign policy analysis is often divided into three approaches: the rational actor model, the organizational behavior model, and the governmental (bureaucratic) politics model (Allison and Zelikow 1999). These three models can be loosely matched, in order, with the three predominant frameworks used in International Relations: realism, constructivism, and liberalism. Classical realism highlights the competitive nature of international politics and the state's need for power, a zero-sum concept, to achieve policy goals. Statesmen must constantly pursue power to such a degree that it is seen not only as a means but as an end (Morgenthau 1978, 5-9). While state policy is understood as purposive action of a unified entity, classical realism looks to individual, state, and systemic factors as influencing the formation of such action. Structural realism is expressly not a theory of foreign policy, yet it has implications for foreign policy nonetheless. It treats all states as unitary actors with the common predominant goal of survival. ${ }^{2}$ Waltz relies on an assumption that states learn from watching others and will emulate successful states (1979, 117-118), while Keohane assumes straight-forward rationality $(1986,7)$. In either case, domestic level factors are seen as secondary to an appreciation of the constraints inherent in the systemic distribution of power. Social constructivism emphasizes the dynamism of state identity and interests and explains how processes of social interaction can reorient state goals (Wendt 1992). Organizational behavior, to include organizational culture, reflects this process-driven focus for explaining foreign policy choices. Finally, liberalism squares with the bureaucratic politics approach that sees policy outputs as the result of competition between various domestic interest groups with different preferences, highlighting the non-unitary nature of the state and the dis- 
jointed policy choices that often emerge (Moravcsik 1997, 516-520).

In the realm of decision-making regarding the acquisition of nuclear arms, this tripartite typology is mirrored in Sagan's seminal work (1997, 55). Therein, Sagan identifies motivations based on security, norms, and domestic politics, categories corresponding to realism/rational actors, constructivism/organizational behavior, and liberalism/governmental politics, respectively. Most works have focused on one of these three categories. For example, Thayer (1995) provides a realist argument, highlighting the primacy of national security threats in the decision to pursue nuclear arms. Hymans (2006) offers a constructivist explanation focused on the individual level of analysis, by exploring how an individual leader's perception of status relative to a "key comparison other" may impact proliferation decisions. Solingen's (2007) domestic politics argument looks at the strength of internationalist economic interests within the state, contending that strong externally-oriented trading interests will diminish the pursuit of nuclear arms. Of note, Lavoy (2006) combines security and domestic politics in his "myth-making" model, highlighting how leaders mobilize domestic support to meet security goals by anchoring pro-nuclear ideas to existing cultural precepts. Although not selfidentified as such, this model represents an example of neoclassical realism.

Quantitative studies attempting to test these theories offer useful broad-brush looks at influences on proliferation, but often utilize gross measures as proxies for more nuanced concepts (Singh and Way 2004; Jo and Gartzke 2007; Bleek 2010). For example, measures of threat used by Singh and Way are participation in an enduring rivalry and frequency of participation in militarized interstate disputes (869). These measures may fail to capture existing perceptions in cases such as Japan, where such involvement is lacking, yet where the perception of threat is acute. Montgomery and Sagan (2009) offer a comprehensive review of the problems quantitative studies face with measurement as well as access to data.

Different studies find different levels of support for the various theories. Although the realist-security rationale receives the most support, it cannot explain all cases of proliferation- or non-proliferation (Sagan 1997, 85; Jo and Gartzke 2007, 176; Gartzke and Kroenig 2009, 155; Potter and Mukhatzhanova 2010, 2-3; cf. Hymans 2010, 20-21). Domestic preferences, strategic culture, pursuit of prestige, and the characteristics of individuals have all influenced decisions to seek nuclear arms in particular cases. Indeed, logic suggests that proliferation is more likely when multiple causes converge (Sagan 1997, 85; Singh and Way 2004, 861). The ability to consider multiple causes at different levels of analysis gives neoclassical realism its strength. As Bajema notes, "Given its consideration of both external and internal variables, neoclassical realism offers significant potential ... for explaining and forecasting nuclear proliferation" $(2010,63)$.

While this breadth sacrifices parsimony and renders neoclassical realism vulnerable to charges that it cannot be falsified, such concerns seem a small price 
to pay if it provides greater accuracy and insight to actual policy-making. As discrete foreign policy choices rather than general patterns of alignment are the subject of inquiry for neoclassical realism, Waltzian simplicity is not an option. However, establishing whether the marginal explanatory benefits attendant to inclusion of domestic variables are worth the increased theoretical complexity is a matter of individual preference. In either case, given the inherently eclectic nature of neoclassical realism, it is important to specify what evidence would be inconsistent with its logical underpinnings. In the next section, I explain neoclassical realism more fully, identifying what it is and what it is not, then lay out my version that adds consideration of principal-agent issues.

\section{NEOCLASSICAL REALISM}

Neoclassical realism, a term first coined by Gideon Rose $(1998,146)$, accepts the structural realist precept that systemic constraints are the primary influences shaping a state's foreign policy. Specifically, the amount of power a state possesses within the international system is the single most important variable. Yet, power is difficult to measure, leading to varying perceptions of its distribution at any given time. There is no authoritative objective ranking of state power to which statesmen might turn in order to calibrate their foreign policies. Rather, perceptions of power are influenced by domestic considerations. State structure, strategic culture, and psychological biases of decision-makers are domestic variables that affect assessments of power. Thus, the universe of policy options is filtered through policymakers' perceptions of the relevant balance of power resulting in a set of available policy options. ${ }^{3}$ In addition, principal-agent relations of the state and the government act as another intervening filter. Policymakers acting in the name of the state may subordinate state interests to parochial interests.

Contrary to arguments that domestic level variables are reserved for liberalism (Legro and Moravcsik 1999, 28-34), consideration of domestic level variables does not mandate removal from the realist family of models (Mastanduno et al. 1989, 459; Sterling-Folker 1997, 3; Rathbun 2008, 300-301). Classical realism has long pointed to domestic factors, at both the state and the individual level, as having a major influence on international behavior. For example, Morgenthau $(1978,211)$ noted "National character and, above all, national morale and the quality of government, especially in the conduct of foreign affairs, are the most important, but also the most elusive, components of national power." Other classical realists have highlighted the role of nationalism (Wolfers 1963, 762-763; Aron 2003 (1966, 279-306). Gilpin $(2000,20)$ notes that "Classical realists from Thucydides forward have emphasized the role of ideas and 'identity' in political affairs." Colin Gray, a staunch realist, was among the first generation of scholars to specifically explore strategic culture (1981). Nor are individual traits outside of 
classical realism's reach: "thinkers such as Thucydides, Niccolo Machiavelli, and Hans Morgenthau all explicitly acknowledge the impact of individual personalities on international relations" (Byman and Pollack 2001, 110). Structural realism's identification of the anarchic international structure, rather than human nature, as the motivation for states' pursuit of power resulted in liberalism's domination of domestic-level explanations in the 1980s and 1990s. However, it is the willingness to return to domestic variables that has earned neoclassical realism its "classical" appellation.

To date, most neoclassical realist work has focused on state and societal variables rather than individual-level variables. Stephen Walt's balance of threat theory (1987) looks to the domestic perception of threat-not just the structural distribution of power, making it an early, if unrecognized, example of neoclassical realism. Others looking at domestic factors as key influences include Snyder (1991), explaining instances of overly expansionist foreign policy, and Schweller (1994), explaining bandwagoning behavior. Zakaria (1998) and Taliaferro (2006) each focus on state structure and the ability of governments to mobilize and extract power. Friedberg (2000), Dueck (2006), and Layne (2006) explore constraints and opportunities provided by strategic culture. The individual level work that has been done concentrates on perceptions of power (Wohlforth 1987 and 1993; Friedberg 1988; Christensen and Snyder 1990; Christensen 1997). Relatively unexplored through the lens of neoclassical realism lies the principal-agent issue of placing individual interests ahead of national interests.

Neoclassical realism accepts the "core assumptions" of realism: social groupstypically, but not necessarily, states-are the "key actors," power is the primary concern of these groups, and group interaction is inherently conflictual (Schweller 2003, 325-326). From these core assumptions, one can differentiate neoclassical realism from other frameworks and identify evidence that would be contrary to its expectations. To be sure, neoclassical realism is integrative; thus, no single case can confirm or refute its claims. However, through a collection of case studies employing process-tracing methodology, evidence should accumulate either in support of or against its power-based perspective. For example, neoclassical realism rejects the likelihood of reliance on collective security. Consistent findings of policies that discount self-help or alliances in favor of systemic guarantees of protection would be contrary to neoclassical realism. Neoclassical realism rejects the liberal interdependence and neoliberal institutionalist arguments that regularized interactions lead to more pacific relations. Evidence that policy-makers are more accepting of negative power imbalances due to high volume trading relationships or formal institutional memberships would run counter to neoclassical realist expectations.

Another way of distinguishing neoclassical realism is to view it as a "theory of mistakes" (Schweller 2006, 10). Through its consideration of state and indivi- 
dual level variables, it provides an explanation for why a state deviates from rationalist expectations. Consistent with structural realism, it expects such deviations to result in systemic punishment. That is, when a state acts outside the constraints of power, for example by failing to balance or by over-extension, it will suffer (Rathbun 2008, 296-297). An absence of such penalties would refute neoclassical realism.

The next two sections describe the underpinnings of the neoclassical realist framework advanced here: perceptions of power and principal-agent relations.

\section{Perceptions of Power}

Because it is the primary explanatory variable of neoclassical realism, it is necessary to expressly define power. No better definition of power exists than that offered by Dahl $(1957,202-203)$ half a century ago: the ability to get someone to do that which they otherwise would not have done. While this definition of power may be difficult to empirically measure, it has the irreplaceable advantage of conceptual accuracy. Nonetheless, because of the measurement problem, power is often assessed by comparing one state's material capabilities to another. In this way, two separate concepts-power and material capabilities-become conflated. Power, as Dahl defines it, is an inherently relational concept. It is a zero-sum measure. In a system with a single state, a discussion of power would be meaningless. Conversely, material capabilities are an absolute concept. A state's material capabilities are a measure of the state's stores of the resources in question; not a comparison to the resources of another state. While the balance of material capabilities between two states has great bearing on the dyadic balance of power, material capabilities are not the only elements of power. As Taliaferro (2000-2001, 155) notes, "Purely quantitative indicators of capabilities simply cannot capture decision-makers' assessments." With this, Dahl's definition of power is consistent with the realist recognition that power is a "psychological relation" rather than a material one (Morgenthau 1978, 30). That is, regardless of whether a state possesses a material advantage over a competitor, what matters are the perceptions of that state's leaders regarding its freedom of action with respect to the competitor.

Perceptions of power depend on the balance of objective capabilities between a state and the relevant competitor, a state's domestic structure, strategic culture, and psychological biases of policymakers. Objective capabilities include measures of wealth as well as population, military force, and industrialization, such as found in the Correlates of War Composite Indicator of National Capability (CINC) index (Singer, Bremer and Stuckey 1972) (v.4, 2007). However, even these measures are incomplete. For example, population numbers fail to account for education, technical capacity, unity, or other qualitative ideas. Likewise, quantitative measures of military force may overlook differences in weapons systems, training, and morale. 
Yet, even where the balance of raw resources is known, governments vary in their ability to mobilize and extract usable capabilities therefrom (Taliaferro 2006, 465). A state may have greater latent material capabilities than a competitor, but the government may be able to mobilize only a fraction thereof (Zakaria 1998, 8788). Conversely, a resource-poor state might have in place a regime based on inclusiveness and popular legitimacy, enabling the full mobilization of society's productive capacity. Thus, state structure matters to the perception of power. In addition to regime legitimacy, an effective bureaucracy with centralized direction can enhance extraction of resources.

Strategic culture affects perceptions of power by establishing normatively acceptable behavior. Policies that are not consistent with cultural values will lack public support. Thus, the ability of a government to generate power will vary depending on the particular policy at issue (Yoshimatsu 2012, 108). Moreover, policymakers internalize national cultural values so that their personal preferences will typically reflect cultural norms (Dueck 2006, 19). Accordingly, strategic culture operates not only through public opinion, but by influencing the fundamental ideas of policymakers. In addition to strategic culture, organizational culture can impact policy. Organizational theory contends that organizations adopt shared assumptions and understandings that establish priorities within the organization. As the organization matures, specific issues and means are privileged by the creation of vested interests within the organization dedicated to their protection. While this theory cannot explain the original choices of the organization, it does explain how pathdependent advantages reinforce certain behaviors (Smith 2014).

Where uncertainty or incomplete information prevail, bias can color the governing elites' perceptions of power (Zakaria 1992, 188; Rose 1998, 157-58). Competitors may try to conceal their true capabilities or their resolve regarding a particular issue, actively disseminating misinformation. Even accurate evaluation of one's own capabilities is difficult, as performance in a crisis may differ significantly from training scenarios (Mearsheimer 2009, 244). When information is lacking, individuals' cognitive and affective biases play a greater role in analysis and prediction of behavior (Jervis 1976, 143; Taliaferro 2000-2001, 141). Perceptions will be shaped by both the expectations and the preferences of the beholder. Rather than recognizing the situational imperatives facing a competitor, people typically presume behavior stems from the competitor's dispositional attributes (Jervis 2013, 155). This is particularly pronounced when the policymakers are active goal-driven leaders rather than more cautious reactive players (Hermann et al. 2001, 92) Changing these preconceptions can be challenging, requiring something greater than a simple preponderance of the evidence. Instead of updating perceptions in an incremental way as new information is received, adjustments often come in "shocks" resulting in a new appraisal of the distribution of power (Larson 1997, 711; Zakaria 1998, 11). Accordingly, as Friedberg (1988, 286-288) 
points out, assessments of power are related to, but not determined by, reality.

\section{Principal-Agent Relations}

Perceptions of the distribution of power within the international system set limits to foreign policy choices; yet, "states" cannot act directly. Each state has a particular domestic order that sets rules and develops institutions for governance. Following the principles laid down by these domestic "regimes," specific "governments" are emplaced. Elites within the governments, conditioned by the regimes they serve, act in the name of the state. These three concepts-state, regime, and government-are at times used interchangeably; however, as the interests of these three are not necessarily identical, it is useful to explicitly distinguish between them.

The state is a geographically centered construct consisting of specifically delineated territory and the people residing therein. State interests are the political survival of the state and the well-being of the population (often described as the "nation") within its boundaries. More than simply the aggregation of various interest-groups (Mastanduno et al. 1989, 460) or the preferences of the currentlydominant elites, the state is an ideal, serving as the "true representative of national interests" (Rathbun 2008, 314). As such, despite its collective nature, it can be presented as a rational, unitary actor in the abstract. A regime is the system of governance within a state. It refers to the fundamental underlying principles and structure for determining who gets what within the state (Keohane and Martin 2003, 78; Schweller 2004, 173). For example, in the United States, there has been a single regime since the adoption of the U.S. Constitution in 1787. Conversely, in Iran, the overthrow of the Shah by the Islamists in 1979 ushered in a new regime. The dominant regime interest is continuation of the regime, regardless of whether or not this serves the national interest.

The term government identifies the specific set of individuals who occupy positions of state authority pursuant to the existing regime at any given time (Schweller 2004, 173). These individuals are agents of the state (Morgenthau 1948, 108) rather than reflections of the state. The state is dependent on these officials to act in a fiduciary capacity. Yet, while the state has a consistent set of objective interests, the government officials acting in the name of the state may or may not pursue these interests, despite their charge. Government officials may prioritize regime interests or their own individual parochial political interests at the expense of state interests (Lobell 2009, 51). As Fred Ikle noted, "Most senior officials are guided by a mixture of considerations: on the one hand, unselfish conceptions of the national interest; on the other-less conspicuously perhaps-partisan or personal motivations. If one emphasizes only the personal and factional element, or only the unitary view of the nation's interests, one does not do justice to reality" $(1971,15)$. 
Both regime health and the individual fortunes of governmental elites influence foreign policy. Normally, governments support the regimes that have allowed them to rise to power. Thus, governments are generally highly sensitive to maintaining regime legitimacy. Likewise, governing elites are concerned with personal political standing. Where the regime is threatened internally or where individual elites face removal from office, domestic imperatives may overwhelm policymakers' consideration of systemic constraints. Either or both of these can result in the subordination of state interests to parochial political considerations. For example, the North Korean government has prioritized regime and individual interests over state interests, displaying indifference to national suffering.

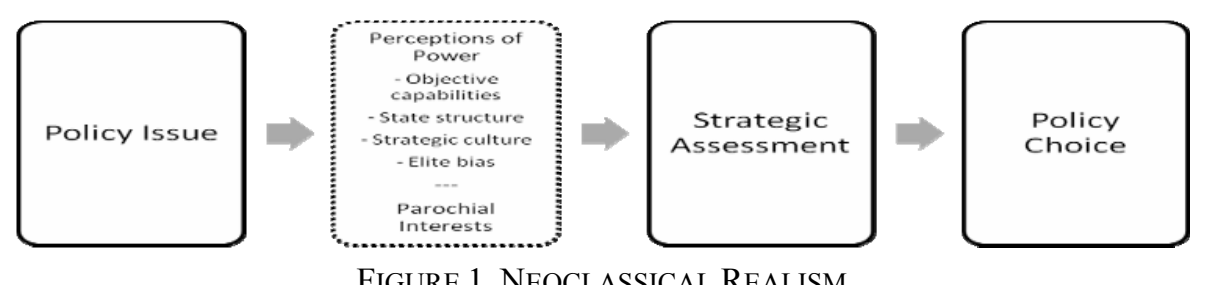

\section{APPLICATION TO SOUTH KOREA'S NUCLEAR POLICY}

Consistent with all variations of realism, this perspective begins with the assumption that all states pursue power. Contrary to structural realism, it does not assume that the only purpose for which states desire power is security. Some states adopt revisionist policies, some adopt opportunist policies: not all are satisfied with the status quo. Thus, the model rejects both the pure balance of power theory of Waltz (1979) and the balance of threat theory of Walt (1987), in favor of the balance of interests theory articulated by Schweller (1998). For South Korea, the primary interests are population security, continued economic growth, and political reunification of the peninsula. With this foundation, we can consider the policy issue of whether South Korea is likely to pursue nuclear weapons.

\section{Perceptions of Power}

For great powers, the relevant consideration is the global distribution of power (polarity); however, for most states, the more pertinent balance of power is that found within regional subsystems. To be sure, the global balance impacts regional subsystems, but it is the immediate neighborhood that garners leaders' attention.

The Republic of Korea's (ROK) primary security threat and key referent for comparing military power is the Democratic People's Republic of Korea (DPRK). After the Korean War, South Korea relied on the U.S.-ROK Mutual Defense 
Treaty as a pillar of its national defense, deterring communist aggression from the north. The U.S. deterrent depended on both conventional forces stationed in South Korea as well as a nuclear threat that included Korean-based tactical nuclear weapons from 1958-1991. Although South Korea demonstrated interest in pursuing its own nuclear force when it perceived diminishing U.S. commitment in the early 1970s, it ultimately chose to end such efforts in the face of strong U.S. opposition (Snyder 2010, 161-162). By the 1980s, South Korea's economic development funded conventional military strength surpassing that of the DPRK in quality, if not quantity. Coupled with the collapse of the Soviet Union, this allowed the withdrawal of U.S. tactical nuclear weapons from South Korea in 1991, although U.S. strategic nuclear forces continue to provide extended deterrence protection.

The expanding military capabilities of China present another threat to South Korea. Should the United States exit the region, nuclear arms would be the only military balance available to South Korea. However, China's apparent strategy of using conventional or civil-security instruments to enhance regional power projection reduces the utility of nuclear arms.

Outside of the Korean peninsula, the residual effects of historical Japanese imperialism continue to play a role in ROK security perceptions. South Korean resentment of Japan has limited the ability of both states' defense partner, the United States, to expand the separate alliances into a strong trilateral relationship. Interestingly, Cha contends that a weakened U.S. regional presence would force South Korea and Japan into a more cooperative relationship in order to balance against a Chinese state with hegemonic ambitions (2000, 263). While this may be true, if Japan were to develop an independent nuclear force, South Korean officials would see this as negatively affecting ROK's regional power, greatly increasing their perceived need for nuclear arms (Pinkston 2004).

When assessing power, leaders consider objective capabilities, state structure, and national strategic culture. Where incomplete information or uncertainty inhibit clear assessments, a policymaker's biases are more likely to shape his or her perceptions.

\section{(1) Objective Capabilities}

Objective measures of relative capabilities suggest South Korean freedom to develop nuclear arms. Using the Correlates of War CINC index (Singer et al. 1972) (v.4, 2007) a five state Northeast Asian subsystem breaks down as follows: China (69\%), Japan (15\%), South Korea (8.3\%), North Korea (4.5\%) and Taiwan $(2.8 \%)$. If Russia is added to the system, it would hold a $12 \%$ share; however, Russian power is predominantly located in Europe. While dated and crude, these figures capture a rudimentary picture of the basic distribution of capabilities. If the 
United States is added to this system, the U.S.-ROK-Japan triad (44\%) would match the China-DPRK dyad (44.7\%), leaving South Korea with a slightly less than 2:1 ratio over the DPRK. China would prefer a non-nuclear South Korea, but would be forestalled from exercising coercive power by the U.S.-ROK alliance. Japan would also prefer a non-nuclear South Korea, but lacks coercive military power as well as will. Outside of a cooperative venture with China, Russia would have little ability to act on the Korean peninsula. Finally, the United States, having made non-proliferation a high-profile issue, would prefer a non-nuclear South Korea, but would only consider diplomatic and economic measures of coercion.

With its well-developed civil nuclear program and an advanced technological base, South Korea's government elites, regardless of partisan ideology, likely perceive that the state has the technical ability to develop an indigenous nuclear arsenal should it wish to do so. A supply of fissile material exists in the form of spent fuel from ROK's civil nuclear energy program that could be reprocessed. ${ }^{4}$ Civil nuclear technology has developed in South Korea to the point where a consortium of Korean companies was able to conclude a multi-billion dollar deal in 2009 with the United Arab Emirates to build four nuclear reactors in Barakah, Abu Dhabi. Moreover, in the aftermath of U.S. acceptance of Iranian uranium enrichment in April 2015, a new U.S.-ROK provisional agreement on peaceful nuclear cooperation (often known as a 123 Agreement) was reached in which the United States agreed to accept South Korean uranium enrichment and spent fuel reprocessing. ${ }^{5}$ This not only facilitates exploration of nuclear arms, but reduces ROK energy vulnerability by providing greater self-sufficiency in the civil nuclear energy program.

\section{(2) State Structure}

South Korea has a representative government, a highly developed set of domestic institutions, and a bureaucracy capable of coordinating complex programs on a national scale. Having emplaced and consolidated democratic reforms over the past few decades, South Korea now enjoys a regime with what one prominent scholar describes as "widespread, robust legitimacy among the mass public" (Hahm 2008, 129). A concerted government effort to generate public support for a nuclear arms program would thus enjoy some presumption of merit.

Policymakers are generally likely to believe the structure of the state allows for the collection and transmission of accurate information in a bottom-up direction and the dissemination and implementation of key policy directives from the top down. While elements of South Korea's scientific community may have an interest in pursuing nuclear arms for reasons of prestige (Ahn and Cho 2014), the embarrassment to the government from the 2004 revelations of prior nuclear experimentation outside of IAEA Safeguards suggests future governments will look for 
and squelch unapproved activity. Indeed, the nuclear bureaucracy was reformed following 2004, splitting functions between various entities. Strong centralized authority in the office of the presidency (Kim 2014), coupled with heightened executive attention, likely provides policymakers with confidence in the ability to control a nuclear arms program if the decision is made to go forward. Other seats of power in the government are limited in their ability to forestall a presidential decision on this issue.

Financially, the South Korean state is well-structured to obtain necessary resources. Opting for a high-mobilization, low-extraction economic model, South Korea's gross domestic product (GDP) ranks in the top 15 in the world with a purchasing power parity estimate of over $\$ 1.6$ trillion in 2013, yet its taxes and other government revenues constitute less than $25 \%$ of GDP, ranking it $133^{\text {rd }}$ globally in terms of public burden (CIA 2014). Nonetheless, annual government revenues still ranked in the top fifteen in the world, at over \$290 billion (CIA 2014). With this strong state apparatus, the government would foresee little economic difficulty initiating a nuclear arms program.

\section{(3) Strategic Culture}

There is no general cultural impediment to South Korea's pursuit of nuclear arms. An overt program to obtain nuclear weapons capability existed from 19681975. Even after agreeing to give up the pursuit of nuclear weapons and joining the NPT, there have been instances of non-compliance with IAEA notification requirements regarding experiments with uranium enrichment and plutonium separation (Kang et al. 2005, 40). Meanwhile, South Korea has developed one of the world's largest civil nuclear energy industries, demonstrating the limited strength of the anti-nuclear lobby in Korea generally. Indeed, in 2013, two-thirds of respondents in a South Korean public opinion poll supported government pursuit of a nuclear arms program (Kim et al. 2013, 9). While such support could rapidly dissipate if pursuit of nuclear arms came with steep economic costs, the regime leaders could appeal to nationalism.

A key facet of South Korean strategic culture is national ethnic identity (Kim 2014), set in juxtaposition to Chinese and Japanese ethnicities. Born from a history of invasions, this national identity highlights Korean vulnerability and the need for vigilance with respect to security (Cha 2001, 115-117). In practice, this has meant recognition of the need for a strong ally in order to survive as an independent polity in a neighborhood marked by the convergence of three great powers: China, Russia, and Japan. In the modern era, the maritime dominance of the United States adds a fourth great power to the mix, allowing South Korea to adopt a realist outlook of building what military power it can, while relying on an offshore-balancer to prevent a local hegemon from arising. Thus, South Korean 
strategic culture includes the nationalist goal of working toward Korean unification and the practical goal of maintaining a strong alliance relationship with the United States. The reluctance of South Korea to downgrade the alliance was seen most recently in its 2014 request (granted) for an indefinite delay to transitioning wartime operational command of the ROK military from the United States to South Korea.

Given traditional U.S. resistance to nuclear proliferation, South Korean development of nuclear arms could severely weaken, if not terminate, this alliance. Moreover, even if policymakers decided to risk the alliance under the belief that Washington's own interests would compel it to maintain its offshore balancing role in Northeast Asia, pursuit of nuclear arms could threaten South Korea's economic well-being by damaging the U.S.-ROK trade and financial relationships. In sum, policymakers are likely to perceive no overwhelming cultural obstacles to nuclear arms per se, but are likely to perceive second order constraints. That is, the state has the power to proceed, but will have to assess the costs and benefits under particular circumstances.

\section{(4) Psychological Bias}

Psychological biases are most likely to affect perceptions under conditions of uncertainty. Through the National Intelligence Service (NIS), military intelligence, and the intelligence arm of the Unification Ministry, as well as through allied assistance, including a trilateral ROK-U.S.-Japan intelligence sharing agreement concluded in December 2014, the South Korean regime is keenly focused on the DPRK threat, yet the difficulty of the target limits the quality of information. North Korea is perhaps the most closed state in the world. Although the NIS has suffered scandals and accusations of politicization (International Crisis Group 2014), the fact that these have been publicized and judicially considered suggests that the NIS is accountable and subject to oversight. Nonetheless, because of uncertain and incomplete information, the conservative organizational culture of the NIS could lead to reporting that develops or furthers policymakers' biases in assessing the balance of power. Liberals would be pre-disposed to view North Korean nuclear arms as bargaining chips, whereas conservatives would be concerned about the effect nuclear arms could have on North Korean risk propensity with respect to brinksmanship. Partisans of either stripe would have to determine whether they believe the North Korean leadership is rational.

In the case of President Park Geun-Hye, her ideological positions of maintaining a strong deterrent threat against North Korea and of focusing on neoliberal market economics with an emphasis on export-led growth create contradictory pressures. Desire to keep a strong deterrent could cause her to over-value information that ROK proliferation would be met with light international concern; 
whereas desire to grow market access could have the opposite effect. While a full profile of President Park lies outside the scope of this work, an assessment would include Park's personal and ideological background. For example, how does the assassination of her mother by a North Korean agent affect her views toward North Korea? How does the assassination of her father, former President Park Chung-hee, by the head of intelligence influence her views of the NIS and its credibility? Does she feel greater pressure to maintain a strong security position due to her role as the first female president of South Korea?

\section{Parochial Interests}

An unpopular president or a government facing domestic unrest could be tempted to rally popular support by turning to nationalism. Whether using a justification of security or prestige, elites could use a nuclear weapons program to mobilize political support for a struggling government or to divert attention from government failures in other arenas. Conversely, in the event of U.S. retrenchment pursuant to a "fortress America" neo-isolationist policy resulting in greater South Korean insecurity, ideological elites could reject consideration of a nuclear arms program even when such might seem appropriate. Likewise, particular officeholders may be motivated to take actions contrary to national interests in order to advance or protect their own personal positions. However, because of the enormity of the nuclear decision and the amount of attention such would generate both at home and abroad, parochial interests are less likely to intrude into nuclear policymaking than in less consequential areas of foreign policy.

When considering environmental constraints, both systemic and domestic, on the pursuit of nuclear arms, South Korean policymakers would likely conclude that the state is objectively and politically capable of pursuing a nuclear arms program. There are no apparent parochial interests currently of sufficient magnitude to overpower this conclusion. Per neoclassical realism, policymakers would then engage in a traditional realist cost-benefit assessment under existing conditions.

\section{Assessment}

When considering a South Korean nuclear arms program, South Korean leaders must assess whether and how the DPRK nuclear arsenal enhances North Korean power. Are nuclear arms solely a defensive deterrent force or do they provide greater coercive power in the eyes of North Korea? Will they be used as a bargaining chip? Are they a potential source of hard currency? Answers to these questions will help determine the costs and benefits associated with South Korean pursuit of nuclear arms.

The majority of South Korean elites probably estimate that North Korean 
leaders understand that any DRPK use of nuclear arms would result in the rapid destruction of the DPRK regime. Thus, despite North Korean rhetoric, South Korean leaders likely place minimal weight on direct nuclear offensive threats from the North. Given geographic proximity and ethnic homogeneity, offensive use on the Korean peninsula would seem particularly difficult for either the DPRK or ROK, assuming the ultimate political goal was to capture economic resources or unify the peninsula under a single government. Even if this is true however, a nuclear advantage could be interpreted as providing escalation dominance sufficient to allow conventional adventurism. Since the second DPRK nuclear test, North Korea has engaged in such adventurism, including the shelling of Yeonpyeong-do, the attack on the Cheonan, and increased ballistic missile testing. Known as the stability/instability paradox, due to the perception that nuclear arms guarantee homeland security (stability) and thereby permit external conventional aggression (instability), this putative advantage could cause South Korea to consider an offsetting nuclear force. As sanctions continue to lack effect and as the North Korean program matures and new capabilities are developed, South Korean leaders will be increasingly apt to view nuclear arms as a gain in North Korean power requiring some offsetting measure.

Nuclear arms would seem to offer little benefit toward reunification. While the desire to unify the peninsula under a single government suggests revisionist aims, South Korean strategic culture does not promote violent conquest. Actual detonation of nuclear arms in North Korea of anything beyond a sub-kiloton yield would be counter-productive to the political aim of building a unified state and would generate intense domestic disapproval. Thus, a counter-deterrent would seem to be the singular purpose of a South Korean arsenal with respect to the DPRK. While this would offer no military protection against North Korean conventional adventurism, it would satisfy the domestic political requirement of standing firm.

Acquiring nuclear arms would undercut the U.S.-ROK alliance, given the current political climate in the United States regarding nonproliferation. Although South Korean military capabilities are likely sufficient to permit the defeat of North Korea independent of allied assistance, the alliance retains substantial value. First, the alliance provides deterrent credibility. Second, in the event of conflict, U.S. military participation would significantly reduce DPRK capacity to inflict civilian casualties. Third, the alliance helps provide regional stability outside the Korean peninsula. Accepting these costs would require essential offsetting benefits.

The replacement of the military regime with a democratic civilian structure in the 1980s brought with it a new pursuit of international legitimacy. A key component of this has been South Korea's participation in international institutions, to include the nonproliferation regime. South Korea has joined nuclear materials export control groups and signed and ratified the IAEA's Additional Protocol, thereby establishing an identity that works against pursuing nuclear arms. This is 
particularly important given South Korea's export-oriented economy. Economic growth has underwritten not only the transformation of South Korea's standard of living, but also its conventional military capabilities. Thus, ensuring market access abroad is a fundamental interest of the regime. Per Solingen (2007, 2010), such outward-looking internationalists will be less inclined to take security actions (i.e. nuclear proliferation) that could upset trading relations and foreign direct investment compared to inward-looking nationalists who will be more likely to prioritize autonomous security measures.

Given these costs, a rational assessment of the current context tends to reject a nuclear weapons program. Even in the event the government found the security situation required a more direct nuclear deterrent threat than that provided by U.S. strategic nuclear forces, the regime could ask the United States to return tactical nuclear arms to South Korea. Such action would allow South Korea to maintain adherence to international commitments, while upgrading the visibility of the nuclear deterrent force (Ramberg 2013).

\section{CONCLUSION}

This paper has presented a framework for understanding foreign policy decision-making. Based on the realist principle that power is the sine qua non of international politics, it adopts a neoclassical realist view that power is a function of perception. In addition to objective capabilities, policymakers consciously consider matters of state structure and strategic culture in determining their government's ability to bring resources to bear.

As applied to South Korean decision-making on nuclear arms, this framework suggests South Korea has the power to develop nuclear arms. No external actor can realistically prevent South Korea from developing nuclear arms if it opts to do so; no domestic constraints appear to be irresolvable obstacles. However, it also suggests that domestic factors militate against pursuing nuclear arms due to questionable military benefit and harm to South Korea's economic interests and international reputation. Yet, this is not the end of the matter as future changes to inputs require regular re-evaluation. Even if the costs of pursuing nuclear arms currently outweigh benefits, policymakers must still consider the costs of other alternatives in the face of anticipated development of the North Korean nuclear arsenal. Ongoing assessment of other options, ranging from preemptive attack to sanctions to negotiations, must be undertaken. It may be that all options are assessed as worse than the status quo; however, maintenance of the status quo may not be a choice that is available for unilateral adoption. In such a case, the "least bad" option becomes the likely choice. Only a model that is attentive to influences at all levels of analysis and is contextually informed can hope to predict dynamic policy choices. 


\section{REFERENCES}

Ahn, Mun Suk, and Young Chul Cho. 2014. A Nuclear South Korea. International Journal 69(1): 26-34.

Albright, David. 2015. Future Directions in the DPRK's Nuclear Weapons Program: Three Scenarios for 2020. ISIS Report, Institute for Science and International Security, Washington, D.C.: Institute for Science and International Security. Accessed March 3, 2015. http:/www.isis-online.org/uploads/isisreports/documents/North_Korea_Nuclear_Futures_26Feb2015-Master-ISIS_ Final.pdf.

Allison, Graham, and Philip Zelikow. 1999. Essence of Decision: Explaining the Cuban Missile Crisis. 2nd. New York: Longman.

Arms Control Association. 2015. Nuclear Weapons: Who Has What at a Glance. Arms Control Association Fact Sheets. February. Accessed February 22, 2015. http://www.armscontrol.org/factsheets/Nuclearweaponswhohaswhat.

Aron, Raymond. 2003(1966). Peace and War: A Theory of International Relations. New Brunswick, NJ: Transaction Publishers.

Bajema, Natasha E. 2010. Beyond the Security Model: Assessing the Capacity of Neoclassical Realism for Forecasting Nuclear Proliferation. in Fo-recasting Nuclear Proliferation in the 21st Century: The Role of Theory, eds. William C. Potter and Gaukhar Mukhatzhanova. Stanford, CA: Stanford University Press, 1: 58-79.

Bleek, Philipp C. 2010. Why Do States Proliferate? Quantitative Analysis of the Exploration, Pursuit, and Acquisiton of Nuclear Weapons. in Forecasting Nuclear Proliferation in the 21st Century: The Role of Theory, eds. William C. Potter and Gaukhar Mukhatzhanova, Stanford, CA: Stanford University Press, 1: 159-192.

Byman, Daniel L. and Kenneth M. Pollack. 2001. Let Us Now Praise Great Men: Bringing the Statesman Back In. International Security 25(4): 107-146.

Cha, Victor D. 2000. Abandonment, Entrapment, and Neoclassical Realism in Asia: The United States, Japan, and Korea. International Studies Quarterly 44(2): 261-291.

Cha, Victor D. 2001. Strategic Culture and the Military Modernization of South Korea. Armed Forces and Society 28(1): 99-127.

Christensen, Thomas J. 1997. Perceptions and Alliances in Europe, 1865-1940. International Organization 51(1): 65-97.

Christensen, Thomas J. and Jack Snyder. 1990. Chain Gangs and Passed Bucks: Predicting Alliance Patterns in Multipolarity. International Organization 44 (2): 137-168.

CIA. 2014. World Factbook. June 20. Accessed March 8, 2015. https://www.cia. gov/library/publications/the-world-factbook/geos/ks.html. 
Dahl, Robert. 1957. The Concept of Power. Behavioral Science 2: 201-215.

Dalton, Toby and Yoon Ho Jin. 2013. Reading Into South Korea's Nuclear Debate. Pacific Forum CSIS. Accessed February 14, 2015. http://carnegieendowment. org/2013/03/18/reading-into-south-korea-s-nuclear-debate.

Dueck, Colin. 2006. Reluctant Crusaders: Power, Culture, and Change in American Grand Strategy. Princeton, NJ: Princeton University Press.

Friedberg, Aaron L. 2000. In the Shadow of the Garrison State: America's AntiStatism and Its Cold War Grand Strategy. Princeton, NJ: Princeton University Press.

Friedberg, Aaron L. 1988. The Weary Titan: Britain and the Experience of Relative Decline, 1895-1905. Princeton, NJ: Princeton University Press.

Friedt, Anita. 2015. U.S. Nuclear Arms Control Policy and Security in the Asia Pacific. Remarks at Japan Institute of International Affairs, Tokyo, February 20.

Gartzke, Erik and Matthew Kroenig. 2009. A Strategic Approach to Nuclear Proliferation. Journal of Conflict Resolution 53(2): 151-160.

Gilpin, Robert. 2000. Global Political Economy: Understanding the International Economic Order. Princeton, NJ: Princeton University Press.

Gray, Colin S. 1981. National Style in Strategy: The American Example. International Security 6(2): 21-47.

Hahm, Chaibong. 2008. South Korea's Miraculous Democracy. Journal of Democracy 19(3): 128-142.

Hecker, Siegfried S. 2015. The Real Threat from North Korea is the Nuclear Arsenal Built over the Last Decade. Bulletin of the Atomic Scientists. January 7. Accessed February 22, 2015. http://thebulletin.org/real-threat-north-koreanuclear-arsenal-built-over-last-decade7883.

Hermann, Margaret G., Thomas Preston, Baghat Korany, and Timothy M. Shaw. 2001. Who Leads Matters: The Effects of Powerful Individuals. International Studies Review 3(2): 83-131.

Hibbs, Mark. 2013. Will South Korea Go Nuclear? Foreign Policy, March 15: 2013. Accessed February 14, 2015. http://foreignpolicy.com/2013/03/15/willsouth koreagonuclear/.

Hymans, Jacques E. C. 2006. The Psychology of Nuclear Proliferation: Identity, Emotions, and Foreign Policy. Cambridge, MA: Cambridge Universiy Press.

Hymans, Jacques E. C. 2010. The Study of Nuclear Proliferation and Nonproliferation: Toward a New Consensus? in Forecasting Nuclear Proliferation in the 21st Century: The Role of Theory, eds. WIlliam C. Potter and Gaukhar Mukhatzhanova. Stanford, CA: Stanford University Press, 1: 13-37.

International Crisis Group. 2014. Risks of Intelligence Pathologies in South Korea. Asia Report, Brussels: International Crisis Group. Accessed March 12, 2015. http://www.crisisgroup.org/ /media/Files/asia/north-east-asia/259-risks-of-in 
telligence-pathologies-in-south-korea.pdf.

Jervis, Robert. 2013. Do Leaders Matter and How Would We Know? Security Studies 22(2): 153-179.

Jervis, Robert. 1976. Perception and Misperception in International Politics. Princeton, NJ: Princeton University Press.

Jo, Dong-Joon and Erik Gartzke. 2007. Determinants of Nuclear Weapons Proliferation. Journal of Conflict Resolution 51(1): 167-194. doi:10.1177/002200 2706296158.

Kang, Jungmin, Peter Hayes, Li Bin, Tatsujiro Suzuki, and Richard Tanter. 2005. South Korea's Nuclear Surprise. Bulletin of the Atomic Scientists 61(1): 4049.

Keohane, Robert O. 1986. Realism, Neorealism, and the Study of World Politics. In Neorealism and its Critics, ed. Robert O. Keohane, 1-26. New York, NY: Columbia University Press.

Kim, Jiyoon, Karl Friedhoff, and Chungku Kang. 2013. The Fallout: South Korean Public Opinion Following North Korea's Third Nuclear Test. Issue Brief No. 46, Seoul: Asan Institute for Policy Studies. Accessed February 12, 2015. http://en.asaninst.org/contents/issue-brief-no-46-the-fallout-south-ko reanpublic-opinion-following-north-koreas-third-nuclear-test/.

Kim, Jiyul. 2014. Strategic Culture of the Republic of Korea. Contemporary Security Policy 35(2): 270-289. doi:10.1080/13523260.2014.927675.

Lavoy, Peter R. 2006. Nuclear Proliferation Over the Next Decade: Causes, Warning Signs, and Policy Responses. Nonproliferation Review 13(3): 433-454.

Layne, Christopher. 2006. The Peace of Illusions: American Grand Strategy from 1940 to the Present. Ithaca, NY: Cornell University Press.

Legro, Jeffrey W. and Andrew Moravcsik. 1999. Is Anybody Still a Realist? International Security 24(2): 5-55.

Mastanduno, Michael, David A. Lake, and G. John Ikenberry. 1989. Toward a Realist Theory of State Action. International Studies Quarterly 33(4): 457-474.

Mearsheimer, John J. 2009. Reckless States and Realism. International Relations 23(2): 241-256.

Montgomery, Alex H. and Scott D. Sagan. 2009. The Perils of Predicting Proliferation. The Journal of Conflict Resolution 53(2): 302-328.

Moravcsik, Andrew. 1997. Taking Preferences Seriously: A Liberal Theory of International Politics. International Organization 51(4): 513-553.

Morgenthau, Hans J. 1978. Politics Among Nations. 5th. New York, NY: Alfred A. Knopf.

Pinkston, Daniel A. 2004. South Korea's Nuclear Experiments. James Martin Center for Nonproliferation Studies. November 9. Accessed March 8, 2015. http://cns.miis.edu/stories/041109.htm.

Potter, William C. and Gaukhar Mukhatzhanova. 2010. Forecasting Prolfieration: 
The Role of Theory, an Introduction. in Forecasting Nuclear Proliferation in the 21st Century: The Role of Theory, eds. William C. Potter and Gaukhar Mukhatzhanova, Stanford, CA: Stanford University Press, 1: 1-12.

Ramberg, Bennet. 2013. Yale Global Online. March 29. Accessed February 25, 2015. http://yaleglobal.yale.edu/content/should-south-korea-pursue-nuclear-arms. Rathbun, Brian. 2008. A Rose by Any Other Name: Neoclassical Realism as the Logical and Necessary Extension of Structural Realism. Security Studies 17: 294-321.

Rose, Gideon. 1998. Neoclassical Realism and Theories of Foreign Policy. World Politics, October: 144-72.

Sagan, Scott D. 1997. Why Do States Build Nuclear Weapons? Three Models in Search of a Bomb. International Security 21(3): 54-86.

Sanger, David. 2015. With U.S. Eyes on Iran, North Korea's Nuclear Arsenal Expanded. New York Times, May 8: A10.

Schweller, Randall L. 1994. Bandwagoning for Profit. International Security 19 (1): 72-107.

Schweller, Randall L. 1998. Deadly Imbalances: Tripolarity and Hitler's Strategy of World Conquest. New York, NY: Columbia University Press.

Schweller, Randall L. 1996. Neorealism's Status-Quo Bias: What Security Dilemma? Security Studies 5(3): 90-121.

Schweller, Randall L. 2003. The Progressiveness of Neoclassical Realism. In Progress in International Relations Theory: Appraising the Field, eds. Colin Eldman and Miriam Fendius Feldman, 311-347. Cambridge, Mass: MIT Press.

Schweller, Randall L. 2004. Unanswered Threats: A Neoclassical Realist Theory of Underbalancing. International Security 29(2): 159-201.

Schweller, Randall L. 2006. Unanswered Threats: Political Constraints on the Balance of Power. Princeton, NJ: Princeton University Press.

Simon, Herbert. 1985. Human Nature in Politics: The Dialogue of Psychology with Political Science. American Political Science Review 79(2): 293-304.

Singer, David J., Stuart Bremer, and John Stuckey. 1972. Capability Distribution, Uncertainty, and Major Power War, 1820-1865. In Peace, War, and Numbers, ed. Bruce Russett, Beverly Hills, CA: Sage, 19-48.

Singh, Sonali and Christopher R. Way. 2004. The Correlates of Nuclear Proliferation: A Quantitative Test. Journal of Conflict Resolution 48(6): 859-885.

Smith, III, Frank L. 2014. American Biodefense: How Dangerous Ideas about BIological Weapons Shape National Security. Ithaca, NY: Cornell University Press.

Snyder, Jack. 1991. Myths of Empire: Domestic Politics and International Ambition. Ithaca, NY: Cornell University Press.

Snyder, Scott. 2010. South Korean Nuclear Decision Making. in Forecasting Nuclear Proliferation in the 21st Century: A Comparative Perspective, eds. 
William C. Potter and Gaukhar Mukhatzhanova, Stanford, CA: Stanford University Press, 2: 158-181.

Solingen, Etel. 2010. Domestic Models of Political Survival: Why Some Do and Other Don't (Proliferate). in Forecasting Nuclear Proliferation in the 21st Century: The Role of Theory, eds. William C. Potter and Gaukhar Mukhatzhanova, Stanford, CA: Stanford University Press, 1: 38-57.

Solingen, Etel. 2007. Nuclear Logics: Contrasting Paths in East Asia and the Middle East. Princeton, NJ: Princeton University Press.

Taliaferro, Jeffrey W. 2000-2001. Security Seeking Under Anarchy: Defensive Realism Revisited. International Security 25(3): 128-161.

Taliaferro, Jeffrey W. 2006. State Building for Future War: Neoclassical Realism and the Resource Extractive State. Security Studies 15(3): 464-495.

Thayer, Bradley A. 1995. The Causes of Nuclear Proliferation and the Utility of the Nuclear Non-proliferation Regime. Security Studies 4(3): 463-519.

Walt, Stephen M. 1987. The Origins of Alliances. Ithaca, NY: Cornell University Press.

Waltz, Kenneth N. 1979. Theory of International Politics. Reading, MA: AddisonWesley.

Weitz, Richard. 2013. South Korea Does Not Need Nuclear Weapons. World Politics Review, February 26: 1.

Wendt, Alexander. 1992. Anarchy is What States Make of It: The Social Construction of Power Politics. International Organization 46(2): 391-425.

Wohlforth, William C. 1987. The Perception of Power: Russia in the Pre-1914 Balance. World Politics 39(3): 353-381.

Wohlforth, William C. 1993. The Elusive Balance: Power and Perceptions During the Cold War. Ithaca, NY: Cornell University Press.

Wolfers, Arnold. 1963. Integration in the West: The Conflict of Perspectives. International Organization 17(3): 753-770.

Yoshimatsu, Hidetaka. 2012. Japan's China Policy in Domestic Power Transition and Alliance Politics. Asian Affairs: An American Review 39: 106-126.

Zakaria, Fareed. 1992. Realism and Domestic Politics: A Review Essay. International Security 17(1): 177-198.

Zakaria, Fareed. 1998. From Wealth to Power: The Unusual Origins of America's World Role. Princeton, NJ: Princeton University Press. 


\section{ENDNOTES}

1 See e.g. recent remarks by Anita Friedt, U.S. Principal Deputy Assistant Secretary of State, Bureau of Arms Control, Verification, and Compliance, discussing U.S. nuclear policy, in which she reiterated "U.S. commitment to ... a world without nuclear weapons" and continued pursuit of "nuclear disarmament," emphasized the "reduced ... role of nuclear weapons in [U.S.] national security strategy," asserted a refusal to build new nuclear warheads, and announced the desire to "do even more" (Friedt 2015).

2 Offensive realists disagree that security is always the primary goal of the state; some states reject the status quo and seek to revise the systemic distribution of power (Schweller 1996).

${ }^{3}$ Theoretically, all policy options could be considered; however, as explained by Simon $(1985,294)$, bounded rationality-something less than the universe-is a more accurate description of reality.

${ }^{4}$ South Korea has pushed for international acceptance of pyroprocessing, an alternative procedure to reprocessing that it claims diminishes weapons proliferation concerns in that it does not separate pure plutonium.

${ }^{5}$ Prior to the Iran deal, the United States held fast to its long-standing refusal to accept enrichment or reprocessing. 